\title{
A Comprehensive Evaluation of Environmental Pollution Characteristics of the Greenhouse Soils (A Case Study in Kaş-Antalya)
}

\author{
Bülent Topcuoğlu \\ Vocational School of Technical Sciences, Akdeniz University, Turkey
}

Copyright $\subset 2017$ by authors, all rights reserved. Authors agree that this article remains permanently open access under the terms of the Creative Commons Attribution License 4.0 International License

\begin{abstract}
A study was carried out in intensive greenhouse areas of Kaş district, Antalya to determine the relation among soil properties and metal characteristics, ground water properties and metal contents and greenhouse plant metal contents. Additional to routine water and soil analysis, a sequential extraction procedure was used to estimate the availability of heavy metals $(\mathrm{Zn}, \mathrm{Cd}, \mathrm{Ni}$ and $\mathrm{Pb})$ in greenhouse soils and several environmental pollution indexes were used to evaluate the size of pollution and risks. Groundwaters of greenhouse area have high conductivity and nitrate content, but heavy metal contents were below the permissible levels. Average total $\mathrm{Cd}, \mathrm{Ni}, \mathrm{Pb}$ and As contents of groundwaters were below the pollutant limits, but $\mathrm{Zn}$ concentrations were exceeded. However, the average heavy metal evaluation index (HEI) values for all metals in groundwaters were below the critical value. The concentrations of heavy metals with the exception of $\mathrm{Ni}$ in soils of greenhouses were generally below the referenced limits. Soil metal speciation showed that the greatest percentage of all metals was present in the residual form, and the mobility of metals declined in the following order: $\mathrm{As}>\mathrm{Zn}>\mathrm{Cd}>\mathrm{Pb}>\mathrm{Ni}$. Single factor and composite pollution coefficient values of all metals with the exception of $\mathrm{Ni}$ were not exceeded critical limit. Anthropogenic and enrichment factor indexes of greenhouse soils indicate that both two parameters showed similar trends and 1 to 9 fold metal enrichments by anthropogenic inputs compared to uncontaminated soil. Potential ecological risk indexes of soil metals except $\mathrm{Ni}$ were found below the threshold value that indicates these metals have a low risk to surrounding environment. All heavy metal concentrations with the exception of $\mathrm{Cd}$ in tomato fruits were found below the permissible heavy metal limits. Although soil $\mathrm{Ni}$ concentration was excessed the pollutant limits, possibly due to low soil mobility factor of $\mathrm{Ni}$, concentration of $\mathrm{Ni}$ in tomato fruit was found very low. However, target hazard quotient (THQ) of tomato fruits was found below the critical value and thus it can be presumable no health risk for $\mathrm{Cd}$
\end{abstract}

metal in short or medium terms. In a comprehensive manner, in addition to total concentrations referenced, environmental risk evaluation methods and soil speciation studies may provide useful information for assessing metal bioavailability and environmental risks.

Keywords Greenhouse Soils, Groundwater, Tomato, Metal Speciation, Metal Mobility, Pollution Indexes

\section{Introduction}

The impact of heavy metal pollution of soils on food metal content and underground water quality has become a public concern. Heavy metals are of considerable environmental concern due to their toxicity, wide sources, non-biodegradable properties and accumulative behaviours [1].

Due to intensive use of agrochemicals in greenhouse soils, heavy metals are become common pollutants in greenhouse soils and near environment. Repeated amendments of organic matter and intensive use of fertilizers, metal-enriched chemicals and biocides may cause soil and environmental pollution in greenhouses. Although greenhouse areas a have great impact on environment due to intensive use of agrochemicals, little attention has been paid to metal accumulation in greenhouse plants, metal contents of ground waters around greenhouses and heavy metal speciation and metal bioavailability and environmental pollution assessment in greenhouse soils with respect to comprehensive and integrated environmental evaluation.

The impact of agricultural activity on water sources has been widely acknowledged and its impact on surface water systems has been described in numerous studies [2]. Especially, the relationship between agricultural practices and the dissolution of nitrate in groundwater, as well as other pollutants have been studied in a number of case studies [3]. 
Leafy vegetables grown in heavy metals contaminated soils accumulate higher amounts of metals compare to those grown in uncontaminated soils [4]. Heavy metal accumulation in plants depends upon plant species and soil properties, and efficiency of plant metal absorption is evaluated by either plant metal uptake or soil-to plant transfer factors of metals [5].

Most of recently reported studies dealing with the evaluation of heavy metal contamination in soils use only the total content of heavy metal as a criterion for determining their potential effect on the environments. However, total concentrations of heavy metals provide inadequate information for assessing their bioavailability or toxicity [6].

The maximum permissible concentrations of heavy metals in surface soils are normally based on total concentration, although it is the bioavailable metal fraction that possesses environmental concern [7]. Nevertheless, these criteria are insufficient since mobility, environmental diffusion and bioavailability largely depend on soil physico-chemical characteristics and, likewise, on trace metal chemical [8]. Heavy metals are often adsorbed or occluded by carbonates, organic matters, Fe-Mn oxides and primary or secondary minerals [9]. Since plants take up most nutrients from the soil solution, it is often assumed that the dissolved metals are readily available to organisms [10]. Due to potential toxicity of heavy metals to human life and environment, determining the chemical form of heavy metals in greenhouse soils is an important approach of chemical characterization and can provide useful information on its mobility and bioavailability. From an environmental point of view, the evaluation and forecast of food contamination is related to the bioavailable fraction of heavy metals in soil. Although total heavy metal content in soils provide a convenient means of expressing a measure of pollution, such measure are generally deficient in predicting toxicity of metal pollutants. Therefore, the chemical form is of great significance in determining the potential bioavailability and remobilization of the soil metals [11].

Today many environmental pollution risk indexes developed for water and sediments can be used for soils, organic matter and other environmental materials. Although several establishment criteria developed for soils depend on total concentrations, these criteria were frequently unsatisfied for a comprehensive environmental risk prediction. The aim of this study was to provide information on the metal accumulation in ground water and greenhouse plants, metal speciation and metal bioavailability in the greenhouse soils and also evaluate metal enrichments in ground waters, greenhouse soils and plants and paradoxes of soil metal establishments and soil pollution indexes versus to soil characteristics in greenhouse soils.

\section{Materials and Methods}

\subsection{Study Bases and Field İnvestigation}

The experiment was conducted on the major greenhouse vegetable growing area located at Kaş in the western part of Antalya, Turkey. The site studied is intensively cultivated and is not industrialized area. The experiment was carried out at greenhouse region and soil samples were taken from ten sampling points and 30 greenhouse were tested (Figure $1)$.
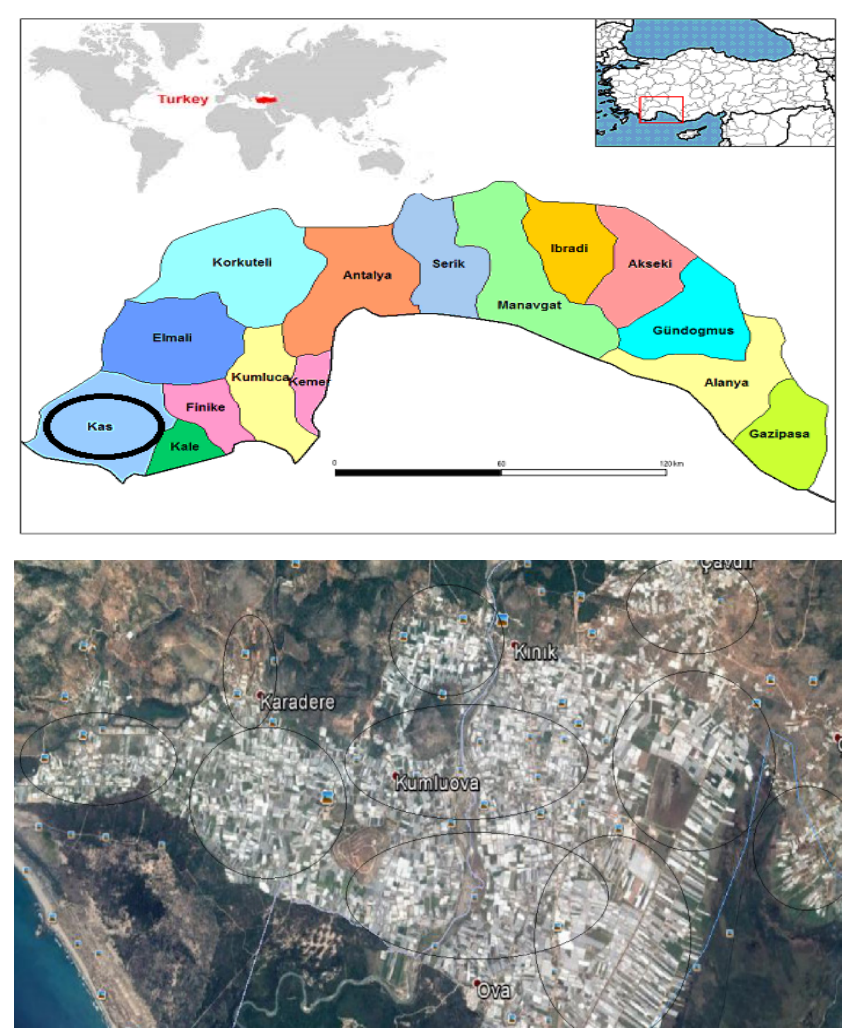

Figure 1. Map of greenhouse regions and sampling points of Kaş, Antalya

The geological materials of greenhouse area are mainly of calcareous nature and adjacent to Mediterranean Sea with average $9-10 \mathrm{~m}$ altitude. The land is influenced by a Mediterranean climate with a high average annual rainfall (782,9 $\mathrm{mm} /$ year), the annual average temperature being around $19,6{ }^{\circ} \mathrm{C}, 54 \%$ average humidity and 8,11 hours average sunshine duration. As for greenhouses, the annual temperature is higher inside than outside, and most of them are watered by sprinklers with ground water source at the same point. All greenhouses have passive ventilation to control temperature and humidity inside. A great number of greenhouse soils are artificially built up with a different layer of sand, organic matter and other soil source.

\subsection{Sample Collection, Treatment and Analysis}

Groundwater samples were collected from ten greenhouse sites to analyze for heavy metals and other properties. Water samples were collected in polyethylene bottles (washed with detergent then with double-distilled water followed by $2 \mathrm{M}$ nitric acid, then double-distilled water again and finally with sampled water). Water samples were acidified with $10 \%$ $\mathrm{HNO}_{3}$ for metal analysis, brought to the laboratory and kept refrigerated until needed for analysis. Water $\mathrm{pH}$, electrical 
conductivity (EC) and nitrate were measured on site. Nitrate was determined by the Cadmium Reduction Flow InjectionMethod, Standard Method $4500 \mathrm{NO}_{3}-\mathrm{N}$ [12]. $\mathrm{pH}$ was measured by digital $\mathrm{pH}$ meter, electrical conductivity was measured by conductometry according to standard methods recommended by APHA [13]. To determine heavy metals in water samples, $10 \mathrm{ml}$ of aqua regia and $1 \mathrm{ml}$ of perchloric acid added to $100 \mathrm{ml}$ of water samples in a culture test tube, then incubated at $80^{\circ} \mathrm{C}$ in a water bath, after total digestion and subsequent cooling, the solution was diluted to $50 \mathrm{ml}$ and analyzed for heavy metals. $\mathrm{Zn}, \mathrm{Cd}, \mathrm{Ni}$ and $\mathrm{Pb}$ concentrations of water samples were analysed using ICP-MS under optimised measurement conditions

Greenhouse soil samples were taken at a depth of 0 to 20 $\mathrm{cm}$ and these were air-dried, sieved $(<2 \mathrm{~mm})$ and stored in polyethylene bags sealed awaiting analysis. Electrical conductivity (EC) and $\mathrm{pH}$ were measured a soil: water ratio of 1:2. cation exchange capacity (CEC) was determined by $0.1 \mathrm{M} \mathrm{NN}_{4} \mathrm{AoC}$ extraction; $\mathrm{CaCO}_{3}$ content was determined by the calcimeter; organic carbon was measured by wet oxidation; and texture was determined by Bouyoucos hydrometer method.

Sequental extraction method [14] was applied to soil samples to identify metal fractions. The heavy metal sequential extraction procedure had the following steps:

F1. $1 \mathrm{M} \mathrm{MgCl}_{2}(1: 8 \mathrm{w} / \mathrm{v}, \mathrm{pH} 7)$ for $1 \mathrm{~h}$ at room temperature; metals in soil solution and in exchangeable forms.

F2. $1 \mathrm{M} \mathrm{NaOAc}(1: 8 \mathrm{w} / \mathrm{v}, \mathrm{pH} 5)$ for $5 \mathrm{~h}$ at room temperature; metals mainly in the carbonate fraction.

F3. $0,04 \mathrm{M} \mathrm{NH} \mathrm{N}_{2} \mathrm{OH} / \mathrm{HCl}$ in $25 \%(\mathrm{v} / \mathrm{v}) \mathrm{HOAc}(1: 20 \mathrm{w} / \mathrm{v})$ for $6 \mathrm{~h}$ at $96{ }^{\circ} \mathrm{C}$; metals associated with $\mathrm{Fe}$ and $\mathrm{Mn}$ oxides.

F4. $3 \mathrm{ml} \mathrm{0,02} \mathrm{M} \mathrm{HNO}_{3}+5 \mathrm{ml} 30 \% \mathrm{H}_{2} \mathrm{O}_{2}(\mathrm{pH} 2)$ for $3 \mathrm{~h}$ at $85^{\circ} \mathrm{C}$; metals associated with organic matter.

F5. HNO3-HCl digestion; residual fraction.

For the determination of 'total' heavy metal concentrations, soil samples were digested in aqua regia $(1: 3$ $\mathrm{HNO}_{3} / \mathrm{HCl}$ ) and $\mathrm{HCLO}_{4}$ according to the international standard [15]. $\mathrm{Zn}, \mathrm{Cd}, \mathrm{Ni}$ and $\mathrm{Pb}$ concentrations of greenhouse soil samples were analysed using ICP-MS under optimised measurement conditions, and values were adjusted for oven dried $\left(12 \mathrm{~h}\right.$ at $\left.105^{\circ} \mathrm{C}\right)$ material.

Tomato fruit samples were collected at the full ripening stage from each greenhouse. The samples were washed throughly with tap water and rinsed with deionized water. Fruit samples were dried at $70{ }^{\circ} \mathrm{C}$ in a forced-air oven, ground in an agate mortar and then digested in aqua regia $\left(1: 3 \mathrm{HNO}_{3} / \mathrm{HCl}\right)$. After cooling to the room temperature, residue was diluted with deionized water and analysed using ICP-MS under optimised measurement conditions, and values were adjusted for oven dried $\left(12 \mathrm{~h}\right.$ at $\left.105^{\circ} \mathrm{C}\right)$ material.

\subsection{Evaluation Methods of Contamination}

\subsubsection{Heavy Metal Evaluation Index (HEI) of the Groundwaters'}

Heavy metal evaluation index (HEI), gives an overall quality of the water with respect to heavy metals is computed as:

$$
H E I=\sum_{i=1}^{n} \frac{H_{C}}{H_{m a c}}
$$

where $H_{c}$ and $H_{m a c}$ are the monitored value and maximum admissible concentration of its parameter, respectively [16].

\subsubsection{Metal Mobility Factor}

Due to some metal forms are strongly bound to soil components than those extracted in F1 and F2, the mobility of metals in soil samples may be evaluated on the basis of absolute and relative content of fractions weakly bound to soil component. Mobility of soil metal was computed based on the metal fractions theoretically mobile fractions in sequential extraction procedure, where the metals are softly bound to the solid phases. Relative index of metal mobility was calculated as a 'mobility factor' (MF) [23] on the basis of the following equation:

$$
M F: \frac{\left(F_{1}+F_{2}+F_{3}\right)}{\left(F_{1}+F_{2}+F_{3}+F_{4}+F_{5}\right)} \times 100
$$

This equation is largely describes the potential mobility of metals [11]

\subsubsection{Single-Factor and Composite Pollution Index of Soils}

Single-factor pollution index $(\mathrm{Pi})$ has been used to evaluate the degree of multi-element contamination. This is considered a better method of evaluation because heavy metals contamination in the surface environment is associated with a cocktail of contaminants rather than one element. Single-factor pollution indices are indicators used to calculate only one metal contamination [17].

$$
P_{i}: C_{i} / S_{i}
$$

where $P i$ is the single factor pollution index or contamination factor of heavy metal; $C i$ is the measured contamination value of heavy metal, $S i$ is the environmentally background contamination value of heavy metal.

Composite pollution Index was applied to assess the quality of soil environment widely and was defined as :

$$
P I_{\text {Nemerow }}=\sqrt{\frac{\left(\frac{1}{m} \sum_{i=1}^{m} P_{i}\right)^{2}+P_{\text {imax }}}{2}}
$$

where $P i$ is the single factor pollution index or contamination factor of heavy metal, $P_{\text {imax }}$ is the maximum values of the single pollution indices of all heavy metals, $m$ is the count of the heavy metals species [17].

\subsubsection{Anthropogenic Factor (AF)}

Anthropogenic factor (AF) reflects the degree of contamination relative to the average composition of the respective metal in soils or to a measured background value from geologically similar but uncontaminated area. AF is expressed as:

$$
A F: C_{m} / B_{m}
$$

where $\mathrm{Cm}$ is the measured concentration in soil and $\mathrm{Bm}$ is the 
background concentration of the metal. Bm values are either taken from the literature or directly determined from a geological similar but uncontaminated area [18].

\subsubsection{Enrichment Factor (EF) Indexes of Soil}

Enrichment factor (EF) has been defined the extent of metal contamination compared to the background area. An element enrichment factor (EF) was initially developed to speculate on the origin of elements in the atmosphere, precipitation, or seawater, but it was progressively extended to the study of soils, lake sediments, peat, tailings, and other environmental materials [19].

The Formula to calculate EF is:

$$
E F=\left(C_{i} / C_{i e}\right)_{S} /\left(C_{i} / C_{i e}\right)_{R S}
$$

where $\mathrm{Ci}$ is the content of element in the sample of interest or the selected reference sample, and $\mathrm{C}_{\mathrm{ie}}$ is content of immobile element in the sample. So $\left(C_{i} / \mathrm{Cie}\right)_{S}$ is the heavy metal to immobile element ratio in the samples of interest, and $\left(C i / C_{i e}\right)_{R S}$ is the heavy metal to immobile element ratio in the selected reference sample [20].

\subsubsection{Ecological Risk Factor Indexes}

An ecological risk factor (Er) to quantitatively express the potential ecological risk of a given contaminant suggested by Hakanson [21] is:

$$
R I=\sum_{i=1}^{n} E_{r}^{i} ; \quad E_{r}^{i}=T_{r}^{i} \times C_{f}^{i}
$$

where $T_{r}$ is the toxic-response factor for a given substance, and $C_{f}$ is the contamination factor, $n$ is the count of the heavy metal species. Although the risk factor was originally used as a diagnostic tool for the purpose of controlling water pollution, it was successfully used for assessing the quality of sediments and soils in environment polluted by heavy metals.

\subsubsection{Risk Assessment Code (RAC)}

Risk assessment code (RAC) index classifies the risk levels based on the chemical speciation of heavy metals and reflects ecological risks [22]. RAC index was computed based on the bioavailable metal concentrations in terms of percent contribution in geochemical fraction (F1 and F2) in sequential extraction procedure, where the metals are softly bound to the solid phases [23]. RAC determines the availability of heavy metals in sediments by applying a scale to the percentage of heavy metals in exchangeable and carbonate fraction $[6,22]$. In this study RAC parameter is modified to greenhouse soils.

RAC was calculated] on the basis of the following equation:

$$
R A C: \frac{\left(F_{1}+F_{2}\right)}{\text { Total concentration }} \times 100
$$

According to RAC guideline, classification of RAC is: $<1 \%$ : no risk, $1-10 \%$ : low risk; $11-30 \%$ : medium risk; $31-50 \%$ : high risk; $>50$ very high risk [22].

\subsubsection{Heavy Metal Transfer (Bioconcentration) Factor}

Soil-to-plant transfer is one of the key components of human exposure to metals through food chain. Heavy metal transfer factor (TF) is a parameter used to describe the transfer of heavy metals from soil to plant body. The TF of metals in the soil to the aerial part of the plants was defined as the ratio of the heavy metal concentration in the plants to that in the soil [24].

$$
T F=\frac{C_{\text {plant }}}{C_{\text {Soil }}}
$$

where: $\mathrm{C}_{\text {Plant }}$ is heavy metal concentration in plant tissue, $\mathrm{mg}$ $\mathrm{kg}^{-1}$ dry weight; and $\mathrm{C}_{\text {Soil }}$ is heavy metal concentration in soil, $\mathrm{mg} \mathrm{kg}^{-1}$ dry weight.

\subsubsection{Target Hazard Quotient (THQ) of Food}

The target hazard quotient (THQ) was used to characterize the heavy metal health risk of consuming vegetables by children in the four bases. The method was provided by USEPA [25]. The THQ is expressed as the ratio of determined dose of a heavy metal to a reference dose. If the ratio is more than 1 , the exposed population is likely to experience obvious adverse effects. The equation is as follows:

$$
T H Q=\frac{E_{F r} \times E_{D} \times F_{l} \times C_{m} \times 10^{-3}}{R_{f D} \times B_{W} \times A_{T}}
$$

where: $\operatorname{EFr}$ (365days year ${ }^{-1}$ ) is exposure frequency; ED is exposure duration( 70years); FI (g person ${ }^{-1}$ day $^{-1}$ ) is vegetable ingestion; $\mathrm{C}_{\mathrm{m}}$ ( $\mathrm{mg} \mathrm{kg}-1$ on fresh weight basis) is heavy metal concentration in vegetables; $\mathrm{RfD}\left(\mathrm{mg} \mathrm{kg}^{-1} \mathrm{day}^{-1}\right)$ is the oral reference dose; $\mathrm{B}_{\mathrm{w}}$ is the average body weight; AT is averaging time for non-carcinogenic effects (365days year ${ }^{-1} \mathrm{x}$ number of exposure years, assuming 70 years in this study). RfD values for $\mathrm{As}, \mathrm{Cd}, \mathrm{Pb}$, and $\mathrm{Zn}$, were $0.05,0.001$, 0.004 , and $0.3 \mathrm{mg} \mathrm{kg}^{-1} \mathrm{day}^{-1}$, respectively [25].

Statistical analyses were performed by using SPSS-16 for Windows program.

\section{Result and Discussion}

\subsection{Ground Water Analytical Characteristics and Metal Contamination Evaluation}

Certain groundwater characteristics and total heavy metal contents of groundwaters in greenhouse areas are shown in Table 1. Groundwaters in greenhouse areas have generally slightly alkaline reaction, high electrical conductivity and high nitrate content. Mean electrical conductivity exceeded 1 $\mathrm{dS}^{-1}$ indicating that these groundwaters were saline in nature. Specially, total nitrate content of groundwater has exceeded maximum permissible limits for drinking waters. High concentration of nitrate and conductivity values are of course may be due to highly intensive agricultural practices for all season and also low altitude of region and may be cause of seawater intrusion to aquifer. Average total $\mathrm{Cd}, \mathrm{Ni}, \mathrm{Pb}$ and As contents were below the permissible pollution limits, but 
in some sampling sites permissible limits for $\mathrm{Ni}$ and As were exceeded. $\mathrm{Zn}$ concentrations in the many sampling sites were above the drinking water standards.

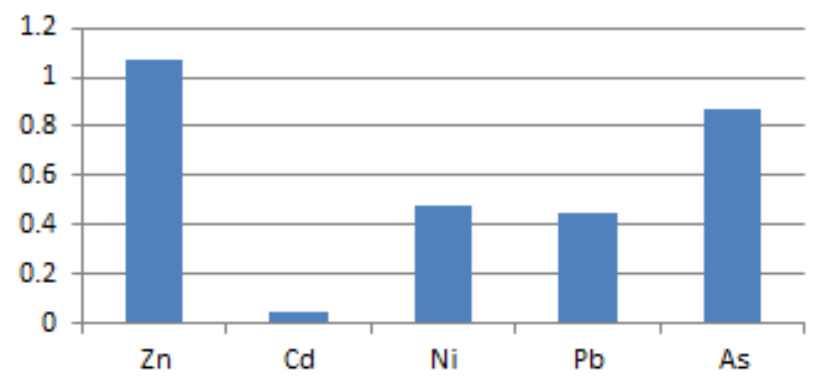

Figure 2. Heavy metal evaluation index (HEI) of the groundwaters.
The mean heavy metal evaluation index (HEI) values for all of metals in groundwaters were below the critical value 40 (Figure 2). Thus, all of groundwater samples may be considered as less contaminated and may be acceptable clean.

\subsection{Soil Analytical Characteristics}

Certain soil analytical characteristics of greenhouse areas are shown in Table 2 . These greenhouse soils have generally slightly alkaline reaction, moderate $\mathrm{CEC}$, high EC values and highly calcareous. These soil characteristics, together with irrigation by sprinklers and agricultural practices, suggest that intensive greenhouses agriculture is the main cause of soil contamination by heavy metals and that theoretically the heavy metal availability will be lower [26].

Table 1. The analytical characteristics and heavy metal concentrations of the groundwaters

\begin{tabular}{|c|c|c|c|c|c|c|c|c|}
\hline Site & $\mathrm{pH}$ & $\begin{array}{c}\mathrm{EC}, \\
\mathrm{micS} \mathrm{cm}\end{array}$ & $\begin{array}{c}\mathrm{NO}_{3}, \\
\mathrm{mg} \mathrm{L}^{-1}\end{array}$ & $\mathrm{Zn}, \mu \mathrm{g} \mathrm{L}^{-1}$ & $\mathrm{Cd}, \mu \mathrm{g} \mathrm{L}^{-1}$ & $\begin{array}{c}\mathrm{Ni}, \\
\mu \mathrm{g} \mathrm{L}^{-1}\end{array}$ & $\mathrm{~Pb}_{\mu} \mu \mathrm{g} \mathrm{L}^{-1}$ & $\mathrm{As}^{-1} \mu \mathrm{g} \mathrm{L}^{-1}$ \\
\hline 1 & 7,14 & 1133 & 71 & 215,8 & 0,25 & 4,65 & 6,91 & 9,53 \\
\hline 2 & 7,22 & 968 & 56 & 198,4 & 0,33 & 5,12 & 6,477 & 9,98 \\
\hline 3 & 7,51 & 985 & 52 & 51,7 & 0,09 & 7,35 & 2,01 & 19,88 \\
\hline 4 & 7,45 & 854 & 47 & 61,8 & 0,12 & 6,89 & 2,13 & 20,55 \\
\hline 5 & 7,24 & 2123 & 100 & 399,8 & 0,23 & 6,35 & 5,61 & 21,83 \\
\hline 6 & 7,35 & 1546 & 95 & 374,1 & 0,29 & 6,44 & 4,88 & 20,78 \\
\hline 7 & 7,97 & 821 & 69 & 181,8 & 0,09 & 6,25 & 5,91 & 19,2 \\
\hline 8 & 7,88 & 792 & 56 & 177,9 & 0,09 & 6,33 & 6,12 & 20,18 \\
\hline 9 & 7,22 & 2031 & 92 & 237,8 & 0,01 & 24,95 & 2,24 & 16,05 \\
\hline 10 & 7,29 & 1856 & 79 & 245,6 & 0,01 & 21,45 & 2,38 & 16,8 \\
\hline Mean & 7,427 & 1310,90 & 71,70 & 214,47 & 0,151 & 9,58 & 4,47 & 17,48 \\
\hline St.D. & 0,28 & 527,46 & 19,17 & 112,45 & 0,115 & 7,27 & 2,031 & 1,403 \\
\hline \multicolumn{2}{|l|}{ Limit values [25] } & & 50 & 200 & 3 & 20 & 10 & 20 \\
\hline
\end{tabular}

Table 2. The analytical characteristics of soils

\begin{tabular}{|c|c|c|c|c|c|c|c|}
\hline Site & $\mathrm{CaCO} 3, \%$ & $\mathrm{pH}\left(\mathrm{H}_{2} \mathrm{O}\right)$ & $\mathrm{EC}, \mathrm{micS} \mathrm{cm}^{-1}$ & $\mathrm{CEC}, \mathrm{meq}^{-100 \mathrm{~g}}$ & Org. C., $\mathrm{g}^{-k g}$ & Clay, $\%$ & Texture \\
\hline 1 & 29.7 & 7.44 & 1428 & 23.4 & 3.29 & 7.28 & Sand \\
\hline 2 & 28.6 & 7.54 & 1463 & 22.0 & 3.25 & 9.96 & Sandy loam \\
\hline 3 & 31.2 & 7.49 & 2424 & 32.0 & 3.10 & 10.68 & Sandy loam \\
\hline 4 & 34.2 & 7.51 & 2258 & 29.6 & 3.25 & 9.96 & Sandy loam \\
\hline 5 & 44.9 & 7.83 & 1127 & 17.0 & 2.66 & 7.28 & Loamy sand \\
\hline 6 & 41.4 & 7.95 & 1114 & 17.5 & 2.88 & 8.85 & Loamy sand \\
\hline 7 & 25.9 & 7.59 & 2629 & 18.1 & 2.34 & 7.68 & Sand \\
\hline 8 & 23.7 & 7.51 & 2356 & 18.6 & 2.45 & 9.84 & Loamy sand \\
\hline 9 & 34.6 & 7.68 & 2277 & 19.2 & 1.22 & 8.28 & Loamy sand \\
\hline 10 & 28.5 & 7.62 & 2144 & 17.6 & 1.38 & 8.62 & Loamy sand \\
\hline Mean & 32.27 & 7.62 & 1922 & 21.5 & 2.58 & 8.84 & \\
\hline St.D. & 6.679 & 0.162 & 574.2 & 5.337 & 0.755 & 1.223 & \\
\hline
\end{tabular}


Table 3. Total metal contents $\left(\mu \mathrm{g} \mathrm{g}^{-1}\right.$ dry wt) of the greenhouse soils and their pollutant limits.

\begin{tabular}{|c|c|c|c|c|c|}
\hline Site & $\mathrm{Zn}$ & $\mathrm{Cd}$ & $\mathrm{Ni}$ & $\mathrm{Pb}$ & As \\
\hline 1 & 71.0 & 0.324 & 199.3 & 15.3 & 4.6 \\
\hline 2 & 92.4 & 0.415 & 135.3 & 32.7 & 5.5 \\
\hline 3 & 88.7 & 0.402 & 236.3 & 31.5 & 5.6 \\
\hline 4 & 86.5 & 0.214 & 184.5 & 32.7 & 5.9 \\
\hline 5 & 83.2 & 0.192 & 186.3 & 28.5 & 4.2 \\
\hline 6 & 65.0 & 0.266 & 226.3 & 66.6 & 6.8 \\
\hline 7 & 61.5 & 0.256 & 205.1 & 71.3 & 7.0 \\
\hline 8 & 67.6 & 0.174 & 1486.0 & 11.1 & 5.5 \\
\hline 9 & 71.6 & 0.172 & 2158.0 & 11.3 & 5.7 \\
\hline 10 & 155.7 & 0.201 & 36.6 & 50.7 & 5.8 \\
\hline St.D. & 27.281 & 0.286 & 225.79 & 6.789 & 0.268 \\
\hline Limits [27] & $20-300$ & $0.03-0.3$ & 50 & $2-20$ & $1-7$ \\
\hline
\end{tabular}


A Comprehensive Evaluation of Environmental Pollution Characteristics of the Greenhouse Soils (A Case Study in Kaş-Antalya)

Table 4. Concentrations of $\mathrm{Zn}, \mathrm{Cd}, \mathrm{Ni}, \mathrm{Pb}$ and $\mathrm{Cr}$ in soil fraction

\begin{tabular}{|c|c|c|c|c|c|c|c|c|c|c|c|}
\hline \multirow[t]{2}{*}{ Metal Fraction } & \multicolumn{10}{|c|}{ Metal Concentration of Sampling Sites $\left(\mu \mathrm{g} \mathrm{g}^{-1}\right.$ dry wt $)$} & \multirow[b]{2}{*}{ Fraction $\%$ mean } \\
\hline & 1 & 2 & 3 & 4 & 5 & 6 & 7 & 8 & 9 & 10 & \\
\hline \multicolumn{12}{|l|}{ Zinc } \\
\hline F1 & 0.34 & 0.30 & 0.29 & 0.32 & 0.33 & 0.30 & 0.32 & 0.32 & 0.33 & 0.35 & 0.42 \\
\hline F2 & 2.85 & 3.02 & 2.78 & 23.02 & 18.31 & 3.32 & 0.30 & 20.32 & 21.8 & 1.95 & 13.24 \\
\hline $\mathrm{F} 3$ & 0.04 & 0.06 & 0.05 & 0.05 & 0.25 & 0.19 & 0.001 & 0.01 & 0.14 & 0.14 & 0.12 \\
\hline $\mathrm{F} 4$ & 0.57 & 0.63 & 2.31 & 1.90 & 1.99 & 1.96 & 0.20 & 0.19 & 0.21 & 0.19 & 1.34 \\
\hline F5 & 65.33 & 81.66 & 79.36 & 55.74 & 56.33 & 57.18 & 58.36 & 45.2 & 47.0 & 139.7 & 84.88 \\
\hline \multicolumn{12}{|l|}{ Cadmium } \\
\hline F1 & 0.004 & 0.005 & 0.004 & 0.001 & 0.002 & 0.002 & 0.003 & 0.001 & 0.001 & 0.002 & 0.87 \\
\hline $\mathrm{F} 2$ & 0.001 & 0.002 & 0.009 & 0.010 & 0.001 & 0.002 & 0.001 & 0.001 & 0.004 & 0.006 & 1.61 \\
\hline $\mathrm{F} 3$ & 0.019 & 0.018 & 0.015 & 0.017 & 0.016 & 0.016 & 0.015 & 0.017 & 0.017 & 0.018 & 7.27 \\
\hline F4 & 0.027 & 0.029 & 0.019 & 0.025 & 0.001 & 0.003 & 0.001 & 0.001 & 0.0001 & 0.001 & 3.51 \\
\hline F5 & 0.282 & 0.369 & 0.361 & 0.150 & 0.162 & 0.229 & 0.229 & 0.145 & 0.144 & 0.173 & 86.80 \\
\hline \multicolumn{12}{|l|}{ Nickel } \\
\hline F1 & 0.34 & 0.33 & 0.33 & 0.32 & 0.32 & 0.32 & 0.32 & 0.82 & 1.32 & 0.33 & 0.23 \\
\hline $\mathrm{F} 2$ & 0.30 & 0.32 & 0.57 & 0.55 & 0.32 & 0.17 & 0.32 & 0.15 & 0.18 & 0.18 & 0.19 \\
\hline F3 & 0.31 & 0.32 & 0.09 & 0.12 & 0.22 & 0.14 & 0.18 & 0.15 & 0.25 & 0.26 & 0.15 \\
\hline $\mathrm{F} 4$ & 2.76 & 2.65 & 1.07 & 1.37 & 0.67 & 0.37 & 0.79 & 0.49 & 0.84 & 0.86 & 0.76 \\
\hline F5 & 189.25 & 219.16 & 218.16 & 171.71 & 178.3 & 207.2 & 208.7 & 1584 & 2021 & 30.1 & 98.45 \\
\hline \multicolumn{12}{|l|}{ Lead } \\
\hline F1 & 0.07 & 0.06 & 0.06 & 0.08 & 0.08 & 0.07 & 0.07 & 0.06 & 0.07 & 0.07 & 0.32 \\
\hline $\mathrm{F} 2$ & 0.02 & 0.02 & 0.11 & 0.10 & 0.03 & 0.03 & 0.01 & 0.01 & 0.02 & 0.02 & 0.15 \\
\hline $\mathrm{F} 3$ & 0.05 & 0.05 & 0.03 & 0.04 & 0.06 & 0.04 & 0.05 & 0.05 & 0.05 & 0.05 & 0.22 \\
\hline $\mathrm{F} 4$ & 1.80 & 1.87 & 1.87 & 1.89 & 1.80 & 1.86 & 1.80 & 1.82 & 1.80 & 1.79 & 8.65 \\
\hline F5 & 13.07 & 26.3 & 27.03 & 26.51 & 24.51 & 54.32 & 58.72 & 7.64 & 7.58 & 44.44 & 90.66 \\
\hline \multicolumn{12}{|l|}{ Arsenic } \\
\hline F1 & 1.38 & 1.14 & 1.13 & 1.11 & 0.12 & 1.13 & 1.21 & 1.48 & 1.51 & 1.85 & 22.13 \\
\hline $\mathrm{F} 2$ & 0.35 & 0.36 & 0.37 & 0.33 & 0.23 & 0.24 & 0.24 & 0.25 & 0.35 & 0.37 & 5.80 \\
\hline $\mathrm{F} 3$ & 0.11 & 0.15 & 0.01 & 0.09 & 0.13 & 0.13 & 0.08 & 0.10 & 0.13 & 0.11 & 1.96 \\
\hline $\mathrm{F} 4$ & 0.27 & 0.24 & 0.40 & 0.42 & 0.45 & 0.36 & 0.24 & 0.26 & 0.14 & 0.15 & 5.56 \\
\hline F5 & 2.39 & 3.28 & 3.27 & 3.80 & 3.26 & 4.66 & 4.88 & 3.12 & 3.13 & 3.39 & 64.56 \\
\hline
\end{tabular}


Table 5. Single-Factor Pollution İndexes (Pi) and Composite Pollution (PI) index of the greenhouse soils

\begin{tabular}{|c|c|c|c|c|c|}
\hline Sampling point & $\mathrm{Zn}$ & $\mathrm{Cd}$ & $\mathrm{Ni}$ & $\mathrm{Pb}$ & As \\
\hline 1 & $0.24 *$ & 0.11 & 2.66 & 0.05 & 0.15 \\
\hline 2 & 0.31 & 0.14 & 1.80 & 0.11 & 0.18 \\
\hline 3 & 0.30 & 0.13 & 3.15 & 0.11 & 0.19 \\
\hline 4 & 0.29 & 0.07 & 2.46 & 0.11 & 0.20 \\
\hline 5 & 0.28 & 0.06 & 2.48 & 0.10 & 0.14 \\
\hline 6 & 0.22 & 0.09 & 3.02 & 0.22 & 0.23 \\
\hline 7 & 0.21 & 0.09 & 2.74 & 0.24 & 0.23 \\
\hline 8 & 0.23 & 0.06 & 19.81 & 0.04 & 0.18 \\
\hline 9 & 0.24 & 0.06 & 28.77 & 0.04 & 0.19 \\
\hline 10 & 0.52 & 0.07 & 0.49 & 0.17 & 0.19 \\
\hline Mean & 0.28 & 0.09 & 6.74 & 0.12 & 0.19 \\
\hline Std. D. & 0.090 & 0.029 & 9.518 & 0.071 & 0.029 \\
\hline Evaluation of Single-factor pollution & \multicolumn{5}{|c|}{$\mathrm{Pi}<1$ : Clean; $1 \leq \mathrm{Pi} \leq 2$ : Potential pollution; $2 \leq \mathrm{Pi} \leq 3$ : Slightly pollution; $3 \leq \mathrm{Pi}$ : Heavy pollution [17] } \\
\hline $\begin{array}{c}\text { Composite Pollution index value (PI) } \\
\text { index value index }\end{array}$ & \multicolumn{5}{|c|}{4,84} \\
\hline Evaluation of Composite Pollution index & \multicolumn{5}{|c|}{$\begin{array}{c}\mathrm{Pi} \leq 0,7 \text { : Clean; } 0,7<\mathrm{Pi} \leq 1 \text { : Warning; } 1<\mathrm{Pi} \leq 2 \text { : Slightly pollution; } 2<\mathrm{Pi} \leq 3 \text { : Moderate; } \mathrm{Pi}>3 \text { : Heavy }[17] \\
2<\mathrm{Pi} \leq \\
0,7 \leq\end{array}$} \\
\hline
\end{tabular}

*: Pi values

Table 6. Anthropogenic and Enrichment factor indexes of the greenhouse soils

\begin{tabular}{|c|c|c|c|c|c|c|c|c|c|c|}
\hline \multirow[t]{2}{*}{$\begin{array}{c}\text { Sampling } \\
\text { point }\end{array}$} & \multicolumn{2}{|c|}{$\mathrm{Zn}$} & \multicolumn{2}{|c|}{$\mathrm{Cd}$} & \multicolumn{2}{|c|}{$\mathrm{Ni}$} & \multicolumn{2}{|c|}{$\mathrm{Pb}$} & \multicolumn{2}{|c|}{ As } \\
\hline & $\mathrm{AF}$ & EF & $\mathrm{AF}$ & $\mathrm{EF}$ & $\mathrm{AF}$ & $\mathrm{EF}$ & $\mathrm{AF}$ & EF & $\mathrm{AF}$ & $\mathrm{EF}$ \\
\hline 1 & 3.08 & 2.33 & 3.14 & 1.79 & 1.20 & 0.90 & 1.16 & 0.87 & 2.05 & 1.53 \\
\hline 2 & 2.94 & 2.61 & 3.32 & 2.23 & 1.05 & 0.93 & 1.14 & 1.01 & 1.99 & 1.75 \\
\hline 3 & 4.22 & 3.13 & 2.23 & 1.25 & 2.21 & 1.64 & 1.28 & 0.95 & 2.14 & 1.57 \\
\hline 4 & 4.43 & 3.78 & 2.29 & 1.48 & 1.88 & 1.61 & 1.28 & 1.10 & 1.95 & 1.65 \\
\hline 5 & 3.09 & 2.76 & 1.47 & 0.99 & 0.88 & 0.79 & 0.86 & 0.77 & 2.63 & 2.33 \\
\hline 6 & 2.82 & 2.74 & 1.52 & 1.12 & 0.84 & 0.82 & 0.88 & 0.86 & 2.70 & 2.60 \\
\hline 7 & 3.09 & 2.77 & 1.58 & 1.07 & 1.12 & 1.00 & 1.27 & 1.14 & 3.42 & 3.04 \\
\hline 8 & 2.98 & 2.43 & 1.53 & 0.94 & 1.16 & 0.94 & 1.79 & 1.46 & 3.25 & 2.63 \\
\hline 9 & 1.91 & 1.58 & 1.38 & 0.86 & 1.05 & 0.87 & 2.29 & 1.89 & 1.75 & 1.44 \\
\hline 10 & 2.14 & 1.64 & 8.72 & 5.06 & 1.03 & 0.79 & 2.04 & 1.56 & 1.12 & 0.86 \\
\hline Mean & 3.07 & 2.58 & 2.72 & 1.68 & 1.24 & 1.03 & 1.40 & 1.16 & 2.30 & 1.94 \\
\hline Std. D. & 0.779 & 0.650 & 2.223 & 1.263 & 0.444 & 0.321 & 0.482 & 0.362 & 0.701 & 0.214 \\
\hline
\end{tabular}


Table 7. Heavy metal potential ecological risk indexes in the greenhouse soil samples

\begin{tabular}{|c|c|c|c|c|c|c|}
\hline \multirow{2}{*}{ Sampling point } & \multicolumn{5}{|c|}{ Ecological Risks (Er) of single-pollutant metals } & \multirow{2}{*}{$\begin{array}{c}\text { General } \\
\text { Ecological Risk } \\
\text { Factor (RI) }\end{array}$} \\
\hline & $\mathrm{Zn}$ & $\mathrm{Cd}$ & $\mathrm{Ni}$ & $\mathrm{Pb}$ & As & \\
\hline 1 & 0.24 & 3.3 & 13.3 & 0.25 & 1.5 & 20.9 \\
\hline 2 & 0.31 & 4.2 & 9 & 0.55 & 1.8 & 18.66 \\
\hline 3 & 0.3 & 3.9 & 15.75 & 0.55 & 1.9 & 24.88 \\
\hline 4 & 0.29 & 2.1 & 12.3 & 0.55 & 2 & 19.36 \\
\hline 5 & 0.28 & 1.8 & 12.4 & 0.5 & 1.4 & 18.27 \\
\hline 6 & 0.22 & 2.7 & 15.1 & 1.1 & 2.3 & 23.38 \\
\hline 7 & 0.21 & 2.7 & 13.7 & 1.2 & 2.3 & 22.24 \\
\hline 8 & 0.23 & 1.8 & 99.05 & 0.2 & 1.8 & 104.32 \\
\hline 9 & 0.24 & 1.8 & 143.85 & 0.2 & 1.9 & 149.3 \\
\hline 10 & 0.52 & 2.1 & 2.45 & 0.85 & 1.9 & 11.21 \\
\hline Mean & 0.284 & 2.64 & 33.69 & 0.595 & 1.88 & 41.25 \\
\hline Std. Deviation & 0.900 & 0.892 & 47.593 & 0.355 & 0.289 & 46.470 \\
\hline Evaluation of EF and RI [21] & \multicolumn{6}{|c|}{$\begin{array}{c}\mathrm{Er}<40 \text { : low; } 40 \leq \mathrm{Er}<80 \text { : Medium; } 80 \leq \mathrm{Er}<160 \text { : İmportant; } 160 \leq \mathrm{Er}<320 \text { : High; } \mathrm{Er}>320 \text { : Very high risk } \\
\mathrm{RI}<150 \text { : Low; } 150 \leq \mathrm{RI}<300 \text { : Medium; } 300 \leq \mathrm{RI}<600 \text { : İmportant; } \mathrm{RI}>600 \text { : Very high risk }\end{array}$} \\
\hline
\end{tabular}

Table 8. Heavy metal concentrations (fresh weight, $\mathrm{mg} \mathrm{kg}^{-1}$ ) of tomato fruits, and metal transfer factors from soil to tomato fruits

\begin{tabular}{|c|c|c|c|c|c|c|c|c|c|c|}
\hline $\begin{array}{c}\text { Sampling } \\
\text { point }\end{array}$ & \multicolumn{3}{|c|}{$\mathrm{Zn}$} & \multicolumn{2}{c|}{$\mathrm{Cd}$} & \multicolumn{3}{c|}{$\mathrm{Nb}$} & \multicolumn{2}{c|}{ As } \\
\hline & $\mathrm{mgkg}^{-1}$ & $\mathrm{TF}$ & $\mathrm{mgkg}^{-1}$ & $\mathrm{TF}$ & $\mathrm{mgkg}^{-1}$ & $\mathrm{TF}$ & $\mathrm{mgkg}^{-1}$ & $\mathrm{TF}$ & $\mathrm{mgkg}^{-1}$ & $\mathrm{TF}$ \\
\hline 1 & 2.11 & 0.297 & 0.008 & 0.247 & 0.154 & 0.008 & 0.141 & 0.092 & 0.009 & 0.020 \\
\hline 2 & 1.85 & 0.200 & 0.034 & 0.819 & 0.133 & 0.010 & 0.137 & 0.042 & 0.008 & 0.014 \\
\hline 3 & 1.96 & 0.221 & 0.030 & 0.746 & 0.333 & 0.014 & 0.197 & 0.062 & 0.007 & 0.012 \\
\hline 4 & 1.73 & 0.200 & 0.037 & 1.729 & 0.249 & 0.013 & 1.855 & 0.568 & 0.008 & 0.014 \\
\hline 5 & 1.13 & 0.136 & 0.008 & 0.417 & 0.173 & 0.009 & 0.135 & 0.047 & 0.007 & 0.017 \\
\hline 6 & 1.02 & 0.157 & 0.025 & 0.940 & 0.185 & 0.008 & 0.125 & 0.019 & 0.006 & 0.009 \\
\hline 7 & 2.55 & 0.414 & 0.074 & 2.891 & 0.182 & 0.009 & 0.140 & 0.020 & 0.009 & 0.027 \\
\hline 8 & 2.22 & 0.328 & 0.078 & 4.483 & 0.165 & 0.001 & 0.137 & 0.124 & 0.014 & 0.026 \\
\hline 9 & 1.03 & 0.144 & 0.009 & 0.523 & 0.187 & 0.001 & 0.118 & 0.104 & 0.026 & 0.046 \\
\hline 10 & 0.97 & 0.062 & 0.026 & 1.294 & 0.197 & 0.054 & 0.122 & 0.024 & 0.016 & 0.027 \\
\hline Mean & 1.66 & 0.216 & 0.033 & 1.409 & 0.196 & 0.013 & 0.141 & 0.110 & 0.012 & 0.021 \\
\hline Std. D. & 0.577 & 0.104 & 0.025 & 1.329 & 0.057 & 0.015 & 0.543 & 0.165 & 0.0007 & 0.109 \\
\hline Limits [27] & 20 & & 0,02 & & 10 & & 2,0 & & 5,0 & \\
\hline
\end{tabular}


Table 9. Target Hazard Quotient of tomato fruits grown in greenhouses

\begin{tabular}{|c|c|c|c|c|c|}
\hline Sampling sites & $\mathrm{Zn}$ & $\mathrm{Cd}$ & $\mathrm{Ni}$ & $\mathrm{Pb}$ & As \\
\hline 1 & 0.06 & 0.07 & 0.07 & 0.36 & 0.0016 \\
\hline 2 & 0.05 & 0.30 & 0.06 & 0.35 & 0.0014 \\
\hline 3 & 0.06 & 0.27 & 0.15 & 0.50 & 0.0012 \\
\hline 4 & 0.05 & 0.33 & 0.11 & 4.69 & 0.0014 \\
\hline 5 & 0.03 & 0.07 & 0.08 & 0.34 & 0.0012 \\
\hline 6 & 0.03 & 0.22 & 0.08 & 0.32 & 0.0011 \\
\hline 7 & 0.08 & 0.65 & 0.08 & 0.35 & 0.0034 \\
\hline 8 & 0.07 & 0.69 & 0.07 & 0.35 & 0.0025 \\
\hline 9 & 0.03 & 0.08 & 0.08 & 0.30 & 0.0046 \\
\hline 10 & 0.03 & 0.23 & 0.09 & 0.31 & 0.0028 \\
\hline Mean THQ & 0.05 & 0.29 & 0.09 & 0.78 & 0.0021 \\
\hline Std. D. & 0.018 & 0.221 & 0.026 & 1.372 & 0.001 \\
\hline
\end{tabular}

The total metal contents of the experimental soil and their pollutant limits were given in Table 3. The results of Table 3 ranged $\left(\mu \mathrm{g} \mathrm{g}^{-1}\right)$ from 61.5 to 155.7 for zinc with a mean of $84.3,0.172$ to 0.415 for cadmium with a mean of $0.262,36.6$ to 2158 for nickel with a mean of 505.4 and 11.1 to 71.3 for lead with a mean of 35.2, 4.2 to 7.0 for arsenic with a mean of 5.6. Average total metal contents except nickel were below the limits of European Union, 86/278/EEC directive to agricultural soils with $\mathrm{pH}>7$. Nickel concentrations in all soil samples were higher than limit values. Other metals were generally in typical soil contents. Although there are no direction limits, arsenic contents of all soil samples were in typical soil content. According to these data, the order for the average content of metals in analysed samples is $\mathrm{Ni}>\mathrm{Zn}>$ $\mathrm{Pb}>\mathrm{As}>\mathrm{Cd}$.

\subsection{Soil Metal Speciation and Contamination Evaluation}

\subsubsection{Metal Speciation}

Concentrations of $\mathrm{Zn}, \mathrm{Cd}, \mathrm{Ni}, \mathrm{Pb}$ and As in soil fractions were given in Table 4. Irrespective of sampling point, the distribution of metals in greenhouse soil samples generally followed the order below for the metals studied.

$\mathrm{Zn}: \mathrm{F} 3<\mathrm{F} 1<\mathrm{F} 4<\mathrm{F} 2<\mathrm{F} 5$

Cd: $\mathrm{F} 1<\mathrm{F} 2<\mathrm{F} 4<\mathrm{F} 3<\mathrm{F} 5$

Ni: $\mathrm{F} 3<\mathrm{F} 2<\mathrm{F} 1<\mathrm{F} 4<\mathrm{F} 5$

$\mathrm{Pb}: \mathrm{F} 2<\mathrm{F} 3<\mathrm{F} 1<\mathrm{F} 4<\mathrm{F} 5$

As: $\mathrm{F} 3<\mathrm{F} 4<\mathrm{F} 2<\mathrm{F} 1<\mathrm{F} 5$

The study of the distribution of metals showed that the greatest percentage of all metals was present in the residual fraction. However, F1, F2 and F3 fractions of $\mathrm{Zn}$ and $\mathrm{Cd}$ metals were higher than other metals. This property possibly gives these metals a high mobility. The most mobile metal fraction was detected in As and the most immobile metal fraction was detected in Ni. Ni largely $(98,45 \%)$ associated with residual phase. The residual phase represents metals largely embedded in the crystal lattice of the soil fraction and should not be available for remobilization except under very harsh conditions [11].

\subsubsection{Mobility of Metals}

The MF values were considerably higher for As, $\mathrm{Zn}$ and $\mathrm{Cd}$. The high MF values have been interpreted as symptoms of relatively high lability and biological availability of heavy metals in soils [28]. The results of the present study suggest that the mobility of the metals declines in the following order: $\mathrm{As}>\mathrm{Zn}>\mathrm{Cd}>\mathrm{Pb}>\mathrm{Ni}$ (Figure 3). Thus, although Ni was the most important threatening metal, its mobility was found very low.

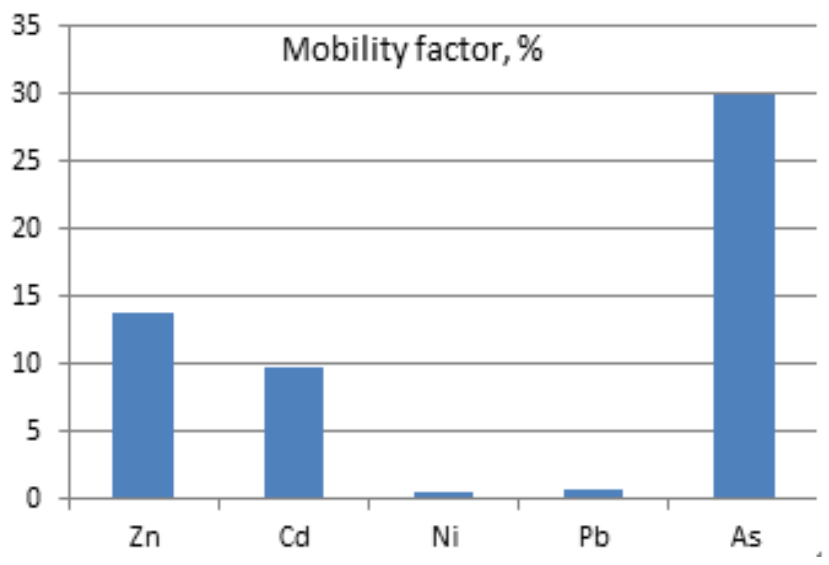

Figure 3. Average metal mobility of greenhouse soils

\subsubsection{Single-Factor and Composite Pollution Index of Soils}

Single-factor and composite pollution coefficient of heavy metals are presented in Table 5. It is clear that all contamination coefficients with the exception of $\mathrm{Ni}$ were not exceeded critical value 1 . Contamination coefficient of $\mathrm{Ni}$ was exceeded critical value in all sampling sites. Although contamination coefficients of other metals were low, due to higher coefficient value of $\mathrm{Ni}$, composite pollution index was determined in heavy pollution risk group. 


\subsubsection{Anthropogenic Factor and Enrichment Factor Indexes of Soil}

$\mathrm{AF}$ and $\mathrm{EF}$ indexes of greenhouse soil were given in Table 6. Estimated values of AF for the heavy metals determined in the soil samples with respect to the uncontaminated soil in the same area were generally greater than critical value 1 , and values ranged 1.91-4.43 for $\mathrm{Zn}, 1.38-8.72$ for $\mathrm{Cd}$, 0,84-2.21 for Ni, 0.86-2.29 for $\mathrm{Pb}$ and 1.12-3.42 for As. This indicates a, 1 to 9 fold metal enrichment by anthropogenic inputs compared to uncontaminated soil.

Enrichment factor values showed similar trends with anthropogenic factor values. Enrichment factor of $\mathrm{Cd}, \mathrm{Ni}, \mathrm{Pb}$ and As metals were below the moderate level limits [19] and approximate to depletion level. Although total Ni concentration of greenhouse soils were above typical soil concentrations and permissible contaminant limits, enrichment factor is very low and also in some sampling sites enrichment factor of $\mathrm{Ni}$ were in depletion level. This may be inferred that $\mathrm{Ni}$ abundancy of parent material of soil is very high and there are less Ni contaminant sources.

\subsubsection{Risk Assessment Code}

According to RAC values of soils, $\mathrm{Ni}(0,42)$ and $\mathrm{Pb}(0,47)$ have no risk to ecosystem. However, $\mathrm{Cd}$ has a low level $(2,48)$ risk and as for $\mathrm{Zn}(13,66)$ and As $(27,93)$ have a medium size risk to ecosystem due to their higher toxicity and percentage in the exchangeable and carbonate fraction which are considered to be easily dissolved into water by acidity and possess an adverse impact on soil biota. The overall pollution degrees of heavy metals are in order of $\mathrm{As}>\mathrm{Zn}>\mathrm{Pb}>\mathrm{Cd}$ (Figure 4).

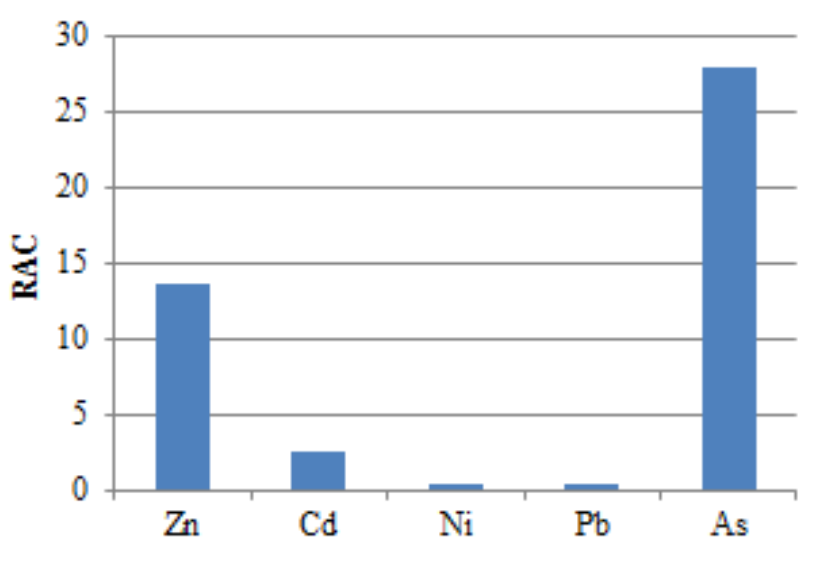

Figure 4. RAC values of soil heavy metals

\subsubsection{Ecological risk factor indexes:}

The potential ecological risk assessment results of heavy metals in greenhouse soils are summarized in Table 7. The average monomial risk factors, Er of heavy metals in greenhouse soils were ranked in the following order $\mathrm{Zn}<\mathrm{Pb}<\mathrm{As}<\mathrm{Cd}<\mathrm{Ni}$. The average monomial risk for heavy metals was found below the 40 that indicate all metals posed low risk to surrounding ecosystem. However, in the sampling point 8 and $9 \mathrm{Er}$ values of $\mathrm{Ni}$ were found 99,05 and 143,85 , respectively. In order to quantify the overall potential ecological risk of observed metals in the greenhouse soils, general ecological risk factor (RI) value was calculated as the sum of all the risk factors. RI values for the sampling points were ranged from 11,21 to 149,3 . Average RI value were found 41,25 and near to low the ecological risk level. However, locally, in the sampling points 8 and 9, RI values - due to high Er values of $\mathrm{Ni}$ element- were found important risk levels.

\subsection{Metal Contamination of Greenhouse Plants}

\subsubsection{Plant Heavy Metal Content and Heavy Metal Transfer/Bioconcentration Factor}

All heavy metal concentrations with the exception of $\mathrm{Cd}$ were found below the permissible heavy metal limits for fresh vegetables [29]. Average $\mathrm{Cd}$ concentrations in tomato fruit were excessed referenced limit $\left(0,02 \mathrm{mg} \mathrm{kg}^{-1}\right)$ a bit more. Although soil Ni concentration was excessed the pollutant limits, possibly due to low soil mobility factor of $\mathrm{Ni}$, concentration of $\mathrm{Ni}$ in tomato fruit was found very low.

The mobility of metals from soil to plants is a function of the physical and chemical properties of the soil and of plant species, and is altered by innumerable environmental and antropogenic factors [30]. In this study the trend of TF value ranges were: $\mathrm{Cd}>\mathrm{Zn}>\mathrm{Pb}>\mathrm{As}>\mathrm{Ni}$.

Heavy metal concentration of tomato plants (fresh tomato fruits) and metal transfer factors from soil to fruit tissues of tomato are shown in Table 8 . The highest average TF was found 3,402 and 1,409 for $\mathrm{Cd}$ in tomato leaf and fruits, respectively. The second high TF was found for $\mathrm{Zn}$ in the either tissues of tomato plant. These possibly might be due to higher mobility factor of $\mathrm{Cd}$ and $\mathrm{Zn}$ in the greenhouse soil (Figure 4.) and may be due to soluble metal participations by agricultural practices or antropogenic factors.

The mobility of metals from soil to plants is a function of the physical and chemical properties of the soil and of plant species, and is altered by innumerable environmental and antropogenic factors [30]. High $\mathrm{Cd}$ accumulation in tomato fruits may be possibly caused by high metal mobility and high enrichment factors of soil Cd. However, although As has the most mobile metal in greenhouse soils, bioconcentration factor was low.

\subsubsection{Target Hazard Quotient of Tomato Fruit}

THQ values of tomato fruits grown in greenhouses are shown in Table 9. As can be seen mean THQ values were found below the critical value 1 . Only $\mathrm{Pb}$ metal in sapling site 4 resulted as 4,69 THQ ratio. Although $\mathrm{Cd}$ concentrations were found above the standard limits, according to these results there cannot be proposed a health risk for $\mathrm{Cd}$ metal in short or medium term. 


\section{Conclusions}

According to water analysis, groundwaters were saline in nature and nitrate contents were exceeded maximum permissible limits for drinking waters. Average total $\mathrm{Cd}$, Ni, $\mathrm{Pb}$ and $\mathrm{As}$ contents were below the pollutant limits, but $\mathrm{Zn}$ concentrations were exceeded. However, the average heavy metal evaluation index (HEI) values for all metals in groundwaters were below the critical value. Thus generally, it can be concluded that all ground waters in regional size may be considered less contaminated, and in point of heavy metals and pollutants is in acceptable limits. High salinity and nitrate contents of groundwaters due to agricultural activities all season, low altitude of region and possible intrusion of seawater to aquifer seem the main threats for sustainable agriculture and ecosystem.

The concentration of heavy metals with the exception of $\mathrm{Ni}$ in soils of Antalya Kaş greenhouses were generally below the limits. Soil metal speciation showed that the greatest percentage of all metals was present in the residual form, and the mobility of metals declined in the following order: $\mathrm{As}>\mathrm{Zn}>\mathrm{Cd}>\mathrm{Pb}>\mathrm{Ni}$. Single factor and composite pollution coefficient values of all metals with the exception of $\mathrm{Ni}$ were not exceeded critical limit. However, due to high total concentration of $\mathrm{Ni}$ in greenhouse soils, composite pollution index was determined in heavy pollution risk group. Anthropogenic and enrichment factor indexes of greenhouse soils indicate that both two parameters showed similar trends and 1 to 9 fold metal enrichments by anthropogenic inputs compared to uncontaminated soil. Potential ecological risk indexes of soil metals except $\mathrm{Ni}$ were found below the threshold value that indicates these metals have a low risk to surrounding environment.

All heavy metal concentrations with the exception of $\mathrm{Cd}$ in tomato fruits were found below the permissible heavy metal limits. However, THQ values of tomato fruits were below the critical value.

The comparison results of risk values of heavy metals based on different methods show that there are several disagreements. Most of these paradoxes in evaluation are mainly depend on the total content of heavy metals as a criterion for determining their potential effect on the environments. Whereas in a comprehensive manner, in addition to total concentrations, environmental risk evaluation methods and soil speciation studies will provide useful information for assessing metal bioavailability or toxicity.

\section{Acknowledgements}

This research was sponsored by TUBITAK (The Scientific and Technological Council of Turkey). Author would like to thank to TUBITAK for the financial support of the project (TOVAG-1110711).

\section{REFERENCES}

[1] Yu, RL., Yuan, X., Zhao, Y.H., Hu, G.R., Tu, X.L. Heavy metal pollution in intertidal sediments from Quanzhou Bay, Chine [J]. Journal of Environmental Sciences, 20(6):664-669, 2008.

[2] Cruz, J.V., Silva, M.O., Diaz, M.I., Prudencio, M.I. Groundwater composition and pollution due to agricultural practices at sete cidades volcano (Azores, Portugal). Applied Geochemistry, 29:162-173, 2013

[3] Heaton, T., Stuart, M., Sapiano, M., Sultana, M. An isotope study of the sources of nitrate in Malta's groundwater. J. Hydrology, 414(415):244-254, 2012.

[4] Al Jassir, M.S., Shaker, A., Khaliq, M.A. Deposition of heavy metals on green leafy vegetables sold on roadsides of Riyadh city, Saudi-Arabia. Bull. Environ. Contaminant. Toxicol., 75: 1020-1027, 2005.

[5] Rattan, R.K., Datta, S.P., Chhonkar,P.K., Suribabu, K., Sing, A.K. Long-term impact of irrigation with sewage effluents on heavy metal content in soils, crops and groundwater: A case study. Agric. Ecosyst. Environ., 109:310-322, 2005.

[6] Sundaray, S.K., Nayak, B.B., Lin, S., Bhatt, D. Geochemical speciation and risk assessment of heavy metals in the river estuarine sediments-A case study: Mahanadi basin, India[J]. Journal of Hazardous Materials, 186:1837-1846, 2011.

[7] Wallace, A., Wallace, G.A. A possible flaw in EPA's 1993 new sludge rule due to heavy metal interactions. Commun. Soil Sci. Plant Anal. 25, 129-135, 1994.

[8] Planquart, P., Bonin, G., Prone, A., Massiani, C. Distribution movement and plant availability of trace metals in soils amended with SS composts: application to low loadings. The Science of the Total Environment, 241:161-179, 1999.

[9] Ross, S.M. Toxic metals in soil-plant system. John Wiley, New York, 1994.

[10] Barber, S.A. Soil nutrient bioavailability: A mechanistic approach. John Wiley, New York, 1984.

[11] Yusuf, K.A. Sequential extraction of lead, copper, cadmium and zinc in soils near ojota waste site. Journal of Agronomy 6(2):331-337, 2007.

[12] Clesceri, L., Greenberg, A.E., Eaton, A.D. 'Standard Methods for the Examination of Water and Wastewater, 20th edition', American Public Health Association, 1998, Washington, DC.

[13] APHA, 'Standard Methods for the Examination by Water Waste Water', 16th Edn. APHA, 1985, Washington.

[14] Tessier, A., Campbell, P.G.C., Bison, M. Sequential extraction procedure for the speciation of particulate trace metals. Anal. Chem. 51, 844-851, 1979.

[15] ISO 11466 International Standard. Soil quality-extraction of trace elements soluble in aqua regia. 03-01, 1995.

[16] Edet, A.E., Offiong, O.E. Evaluation of water quality pollution indices for heavy metal contamination monitoring. A study case from Akpabuyo-Odukpani area, Lower Cross River Basin (southeastern Nigeria), Geojournal, 57, 295-304, 2002.

[17] Cheng, J.L., Shi, Z., Zhu, Y.W. Assessment and mapping of 
environmental quality in agricultural soils of Zhejiang province, China. Journal of Environmental Sciences, 19:50-54, 2007.

[18] Adamu, C., I., Nganje, T.N. Heavy metal contamination of surface soil in relationship to land use patterns: A case study of Benue state, Nigeria. Materials Science and Applications, $1: 127-134,2010$.

[19] Reimann, C., de Caritat, P. Distinguishing between natural and anthropogenic sources for elements in the environment: Regional geochemical surveys versus enrichment factors. The science of the total environment, 337:91-107, 2005.

[20] Zhang, J., Liu, C.L. River in composition and estuarine geochemistry of particulate metals in China-weathering features, anthropogenic impact and chemical fluxes. Estuarine Coast Shelf Sci., 54:1051-1070, 2002.

[21] Hakanson, L. An ecological risk index for aquatic pollution control: A sediment logical approach. Water Research, 14: 975-1001, 1980.

[22] Singh, K.P., Mohan, D., Singh V.K., Malik, A. Studies on distribution and fractionation of heavy metals in Gomti river sediments-A tributary of the Ganges, India $[\mathrm{J}]$. Journal of Hydrology, 312:14-27, 2005.

[23] Jain, C.K., Ran, D. Metal fractionation study on bed sediments of river Yamuna, India. Water Res. 38, 569-578, 2004.
[24] Kachenko, A.G., Singh, B. Heavy metals contamination in vegetables grown in urban and metal smelter contaminated sites in Australia. Water Air Soil Pollution, 169:101-123, 2006.

[25] United States, Environmental Pollution Agency (USEPA), 2007. Integrated risk information system. Available from:(http://cfpub.epa.gov/ncea/iris/index.cfm?fuseaction=ir is.showSubstanceList).

[26] Gil, C., Boluda, R., Ramos, J. Determination and evaluation of cadmium, lead, and nickel in greenhouse soils of Almeria (Spain). Chemosphere, 55, 1027-1034, 2004.

[27] C.E.C. (Council of the European Communities) 1986. Directive of 12 June 1986 on the protection of the environment, and in particular of the soil, when SS is used in agriculture (86/278/CEE). Official Journal of the European Communities, L181, 6-12.

[28] Soon, Y.K., Abboud, S. Trace elements in agricultural soils of North-western Alberta. Can.J. Soil Sci. 70, 277-288, 1990.

[29] WHO/FAO. Joint FAO/WHO food standard programme codex alimentarius commission $13^{\text {th }}$ session. Report of the thirty-eight session of the codex committee on food hygiene, Houston, USA, 2007.

[30] Zurera, G., Estrada, B., Rincon, F., Pozo, R. Lead and cadmium contamination levels in edible vegetables. Bull. Environ. Cont. Toxicol., 38:805-812, 1987. 